\title{
Doha Round and the Least-Developed Countries
}

In the introduction the author referred to paragraph 35 on Small Economies and paragraphs $42-44$ on least-developed countries in the Doha Ministerial Declaration of 14 November 2001. To repeat briefly, paragraph 35 promised to examine trade issues relating to small economies; paragraph 42 committed the ministers to the objective of duty-free, quota-free market access for products originating in LDCs, to facilitate and accelerate negotiations with acceding LDCs and to reaffirm commitments consistent with the mandate of the World Trade Organization that had been undertaken as part of other declarations, and agreed that in designing its work programme for LDCs, the WTO should take into account the Brussels Declaration and Programme of Action. It instructed the subcommittee on LDCs to design such a work programme and report to the General Council by 2002. Paragraph 43 endorsed the Integrated Framework for Trade-Related Technical Assistance to Least-Developed Countries (IF) as a viable model of trade development of LDCs, and requested the Director-General to provide an interim report to the General Council in December 2002 and a full report to the Fifth Ministerial Conference (in Cancún in 2003) on all issues affecting LDCs. Paragraph 44 reaffirmed that provision of special and differential treatment is an integral part of WTO agreements. Except paragraph 44, none of the others strictly speaking, set targets against which the success or failure of Doha Round as a 'Development Round' could be assessed.

The Doha Agenda as described in the WTO's document "Understanding the WTO" (http://www.wto.org/english/theWTO_e/whatis_ e/tif_eltif_e.htm, accessed 4 August 2008) included:

- In agriculture: rural development and food security for developing countries and the needs of least-developed and net food-importing countries; 
- In sanitary and phytosanitary (SPS) measures: more time for developing countries to comply with other countries' new SPS measures, developing countries' participation in setting SPS standards, financial and technical assistance;

- In textiles and clothing: consideration of favourable quota treatment for small suppliers and LDCs;

- In technical barriers to trade: technical assistance to LDCs, a possible six-month 'reasonable time interval' for developing countries to adapt to new measures, and efforts to help developing countries to participate in setting international standards;

- In anti-dumping: developed countries to give 'special regard' to the situation of developing countries when considering applying antidumping measures;

- In subsidies and counter availability measures: sorting out the test for determining whether some developing countries meet the test for being allowed to pay export subsidies, and reaffirming that LDCs are to be exempted from the ban on export subsidies;

- In trade-related aspects of intellectual property rights (TRIPs): technology transfer to LDCs; and

- In cross-cutting issues: clarifications of mandatory and nonmandatory provisions on special and differential treatments, making provisions more effective, methods for incorporating such treatment in new negotiations, and urging developed countries to grant preferences in a generalised and non-discriminatory manner.

The Director-General of the WTO was urged to give priority to provide technical assistance to developing countries to help them implement existing WTO obligations and to increase their capacity to participate more effectively in future negotiations. Technical assistance to developing countries and LDCs for capacity building figures are in several articles (21, 24, 26, 33). However, in the author's view, the WTO has chosen the Integrated Framework (IF) as the primary means for articulating and implementing technical assistance programmes. As discussed in Section 4.7, this framework has not worked well thus far and is most unlikely to perform better in the future. 
Apart from technical assistance, the other items of the Doha Agenda relating to developing countries, including LDCs, could be divided into two broad categories. The first can be described as exhortations and good faith efforts urged on developed countries, almost all of which are essentially voluntary. Without minimising the value of exhortations, moral suasion and ongoing voluntary efforts, it is nonetheless impossible to set time limits for their fulfillment, let alone to set punishments for not fulfilling such items. The second category of items, which constitutes a majority, consists of special and differential treatment of developing countries in general and, in particular, of LDCs, small economies and other groups. These items included, for example, lower rates of required reduction of bound tariffs by developing countries, exempting LDCs altogether from any reduction, allowing a longer time schedule for meeting commitments and so on.

This second category responds to the demands of developing countries and LDCs for concessions and non-reciprocal commitments. In the author's view, giving developing countries a reasonably longer time for meeting the same commitments as developed countries is an entirely appropriate way of taking into account their being at a lower stage of development. However, allowing them to retain higher barriers to trade until the subsequent round of negotiations, with no commitment whatever to reducing them, or reducing barriers to a lesser extent than is required of developed countries, is not in the interests of LDCs in any way. It sustains their mistaken belief that trade restrictions and trade policies are effective instruments for achieving non-trade related and broader goals of development. This is not to deny that poor countries, particularly if they happen to be poorer than others because of factors beyond their control, could do with unconditional and limited resource transfers. In fact, by agreeing to the demands of developing countries for 'concessions' in traderelated commitments and obligations, developed countries are able to avoid making any resource-transfer commitments. This is counterproductive.

There are several reports by the WTO committees and the Secretariat on the state of play in the Doha Round on LDCs. There is also a voluminous record of proposals based on various items of the Doha Negotiating Agenda by individual members and groups of members. Rather than delve into 
this ocean of documents, this book will instead mention two that give a flavour of the current situation.

On 1 December 2006, a report (WT/COMTD/58) was published covering the work of the Committee on Trade and Development, in its regular and dedicated session on small economies and its subcommittee on LDCs. The principal themes addressed at the regular session were largely the standard ones of market access for developing and least-developed countries, and its implications for the development of primary commodity exporters, paragraph 51 of the Doha Declaration for identifying and debating developmental and environmental aspects of the negotiations and so on. This report is simply a factual record of the topics discussed and proposals made, not so much a record of progress made, work remaining to be done or any interim achievements.

A more recent, longer and a more informative report is by the WTO Secretariat (WT/COMTD/SE/W/22 Rev.1) dated 26 November 2007. As a document prepared under the Secretariat's own responsibility, it does not prejudice the right of any member of the WTO to raise its concerns about the work programmes on small economies. However, it attempts to reflect the current state of play of the issues relating to small economies so far discussed in the negotiating and other bodies. Nearly half the report is devoted to the current situation on modalities on market access in agricultural and non-agricultural products. These modalities have since been revised, with the revised negotiating texts circulated in May 2008. The state of play as recorded in the Secretariat's report on domestic regulation, services rules, subsidies and countervailing measures, trade facilitation, and Aid-for-Trade is likely to be revised if and when the negotiations resume. On the whole, and on all these issues from modalities to trade facilitation, the state of play seems to indicate that the obligations and commitments that LDCs, small economies and developing countries more generally will undertake, will be considerably weaker than the corresponding ones that developed countries are to undertake. This is not to say that the countries concerned have agreed to the commitments as stipulated in the draft modalities, etc. It is only to say that the gaps between developed and developing countries in their positions on modalities have narrowed significantly as compared to earlier drafts; whether those that remain are still too large to bridge, or could be bridged in a compromise deal closing 
the Doha Round, is too soon to tell. The collapse of the negotiations at the informal ministerial meeting in Geneva during 21-21 July 2008 suggests that they are still too large.

Turning to the current state of Doha Negotiations, the DirectorGeneral, Pascal Lamy, in his statement of 20 May 2008 said that "these revised negotiating texts illustrate where a convergence lies among the WTO members and where we have more work to do. Very soon our negotiating process will intensify...We are getting closer to our end game." As is to be expected, given his official position, he is optimistic. The author hopes that he is not unduly optimistic, though the history of the negotiations would suggest that he is (as does the current breakdown in talks).

Would the revised negotiating texts of May 2008 with their modalities for agriculture and non-agricultural products, if they are adopted, contribute to enhanced and beneficial participation of LDCs and SVS in World Trade? The fact that India, a major developing country and a leading member of G-20, as well as several other developing country members of the WTO including Brazil, Mexico and South Africa, already rejected them does not augur well for its adoption. ${ }^{1}$ The term of the Bush administration in the US is ending in January 2009, and if it is succeeded by a Democratic Party administration, going by the rhetoric of Mr. Barack Obama, the Democratic presidential candidate, it seems unlikely he would push for a resumption of the Doha negotiations. Even in the unlikely event that he does, he would insist on including on the negotiating agenda labour and environmental standards, which have not been on the agenda thus far. Be that as it may, the author's reading of the negotiating texts suggests that they go a long way in delivering much of what was promised in the Doha Declaration and Agenda by way of special and differential treatment of developing countries in general and LDCs in particular. Whether this will lead to their 'enhanced and beneficial' participation in world trade depends on what the basic constraints are in the first place that reduce effective

1. The Indian Commerce Minister, Mr. Kamal Nath, while disagreeing that only India had differences with the US on farm subsidies, made an offer to close a deal (i.e., to resume Doha negotiations) if the US were to make a symbolic gesture to its farm subsidy by just one dollar. It is likely that he was just making a debating point, and not a serious offer. See: http://www. hinduonnet.com/thehindu/thscrip/print.pl?file $=2008061855781700 . \mathrm{htm} \& \mathrm{date}=2008 / 06 / 18 /$ \&prd $=$ th\& [accessed 4 August 2008] 
participation. To repeat, these are mostly in the domestic arena, primarily of domestic political economy and society.

The Doha revised negotiating texts, if adopted, at best could help developing countries to improve their trade policies and thus help them increase their participation. However, dramatic improvements in trade performance cannot be expected. For example, even after the removal of systemic biases against trade and the dismantling of barriers since the mid80s, India's share in world merchandise trade increased by only half of one per cent over two decades, from 0.5 per cent in 1983 to 1 per cent in 2006. Moreover, in 1948, soon after the conclusion of GATT, India's share was much higher at 2.2 per cent. More generally, the total share in world merchandise trade of Mexico, South and Central America, the Middle East, Africa and Asia (excluding Japan, Australia and New Zealand), which together broadly cover the developing world, was 31.4 per cent in 1948, 26.8 per cent in 1983 and 35.4 per cent in 2006, but the trend for these shares does not reveal the divergent trends among sub-groups. For example, if we exclude South East Asia, which was much more open from the 1960s, and China, which opened in 1978, the share of the remaining countries was 27.1 per cent in 1948, 19.8 per cent in 1983 and 19.6 per cent in 2006 (WTO, 2007, Tables 1-6). This shows that although the period after 1980 is one of growing integration of the developing world with world trade-certainly it reversed the decline in the export share of the developing world as a whole from 1948 to 1983-the gain in export share has largely been in China and South East Asia. Africa and South and Central America have experienced a steady decline in their share of world trade ever since 1948. This suggests that other constraints restricted them from gaining export shares following trade liberalisation. It also confirms that trade liberation per se is not the most effective or first best instrument for achieving distributional objectives or for easing domestic political economy constraints. Quite the contrary: domestic politics is likely to inhibit the adoption of trade liberalisation policies, primarily because of its fear of the short-run adverse distributional consequences trade liberation could have. 